\title{
BESS CLASSIFICATION IN LEVELS OF ADOPTION OF DISTRIBUTED ENERGY RESOURCES (DER) WITH FOCUS ON TRANSFORMATION ELEMENTS
}

\author{
TAYS ESTEFANIA GUTIERREZ CASTRO ${ }^{1}$, EDWIN RIVAS TRUJILLO ${ }^{2}$ \\ \& JESUS MARIA LOPEZ-LEZAMA ${ }^{3}$
}

${ }^{1,2}$ Grupo de investigación Interferencia Electromagnética (GCEM), Ingeniería eléctrica, Facultad de ingeniería, Universidad Distrital Francisco José de Caldas, Bogotá, Colombia

${ }^{3}$ Grupo de investigación en Manejo Eficiente de la energía (GIMEL), Departamento de Ingeniería Eléctrica, Universidad de Antioquia, Medellín, Colombia

\begin{abstract}
Storage Systems are a fundamental part in the growth of the renewable energy market and in the development of transmission networks, contributing to the reduction of fluctuations in the system and maximizing benefits in energy production, by proposing optimization models that help reduce investment. costs in the future. The following document reviews the different types of applications and characteristics of Battery Energy Storage Systems (BESS) and their different contexts in which they were used, from various perspectives in order to be classified with respect to their level of adoption in Distributed Energy Resources. (DER) between: Massive, medium and low integration versus transformation elements (DER) that are: smart grid, energy storage, distributed generation, electric vehicles, response to demand and energy storage. The objective of the document is to show the multidimensionality of Bess and how it has begun to be used in renewable energies, the need for in-depth research and association with other complementary sectors is also created. The results of the review are intended to provide useful information on the current status and future challenges of incorporating (BESS) into Distributed Energy Resource Systems (DER).

KEYWORDS: Electric Vehicles, Demand Response, Smart Grid, Distributed Generation \& Energy Storage
\end{abstract}

Received: Jun 09, 2020; Accepted: Jun 29, 2020; Published: Sep 28, 2020; Paper Id.: IJMPERDJUN20201452

\section{INTRODUCTION}

Distributed Energy Resources (DER) is made up of the following topics: energy storage (ES), electric vehicles (EV), smart grid (SG), demand response (DR) and distributed generation (DG), which have played a fundamental role in the world energy market.

In recent years the use of (BESS) in distributed energy resources (DER) has been expanding due to the versatility of its applications, some topics to be addressed are the incorporation of batteries: as a charging point for electric vehicles incorporating panels photovoltaic [23], with network planning algorithms maximizing benefits [2] [6], incorporated in residential areas reducing self-consumption [35], BESS loading / unloading algorithm [7], incorporation in systems with stability problems [6] or as analysis of economic and technical feasibility [33]. 
Based on what was analyzed, we proceed to establish parameters to classify the different types of paper, taking as a reference the document [1] in which they carry out a study of what types of levels of adoption DER has and what its transformation elements are, this with in order to observe what documents are incorporated into them.

\section{FEATURES AND APPLICATIONS OF BESS: LITERATURE REVIEW}

In this section a review of the literature on published articles on the subject of (BESS) will be presented, the characteristics and applications given by the authors in each of their papers will be analyzed, these are collected in the period of (20092020). Table 1 details the topic covered by each of the authors.

Table 1: Features and Applications of BESS

\begin{tabular}{|c|c|c|}
\hline Ref. & Bibliographical & $\begin{array}{l}\text { Scope and Applicability } \\
\end{array}$ \\
\hline$[2]$ & Kumar, 2019 & $\begin{array}{l}\text { It is proposed to develop an optimization method which is developed at different levels, it } \\
\text { has some generation units and in the part of energy storage systems, batteries are placed } \\
\text { which will serve as backup for the central and distributed auxiliary services. } \\
\text { The objective of level } 1 \text { is to determine the optimal location and size. In level 2, we proceed } \\
\text { to verify that its capacity is sufficient to be able to participate in auxiliary distribution } \\
\text { services. } \\
\text { The effectiveness of the model is seen with a distribution system located in India that results } \\
\text { in more benefits with wider use in wind power generation. }\end{array}$ \\
\hline [3] & Aguado, 2017 & $\begin{array}{l}\text { This document has as an emphasis to control the expansion of the transmission network for } \\
\text { it uses an optimization algorithm, it also implements in its system a type of energy storage } \\
\text { which are batteries of which it studies its applications and characteristics. } \\
\text { The BESS are implemented in order not to expand the transmission network since this leads } \\
\text { to new construction which affects the environment, also reduces demand peaks and is } \\
\text { considered as temporary solutions, alleviating saturation in the network. }\end{array}$ \\
\hline [4] & Divya, 2009 & $\begin{array}{l}\text { The article presents an economic and technical evaluation on implementing BESS (Battery } \\
\text { Energy Storage System) in hybrid electric vehicles and gives a future perspective for battery } \\
\text { technologies. The devices Electric Drive Vehicles (EDV) help to make the electricity grid } \\
\text { more reliable by locating them in auxiliary services and to economically integrate renewable } \\
\text { generation sources. }\end{array}$ \\
\hline [5] & Olaszi, 2017 & $\begin{array}{l}\text { The document presents a comparison of different residential discharge strategies which } \\
\text { reduce self-consumption for residential photovoltaic systems and optimize periods of auto } \\
\text { discharge. } \\
\text { All the simulations that were run were with measurement data in real time, for the base case } \\
\text { it seeks to "store and release immediately", the second concept is smart and seeks to } \\
\text { incorporate and be "network friendly" is a download algorithm manageable, in the third } \\
\text { algorithm is a concept of energy management oriented to the energy market where its } \\
\text { behavior is simulated } \\
\text { The report carries out an optimization web application in which it incorporates the BESS } \\
\text { which help to compare and validate the economic viability }\end{array}$ \\
\hline [6] & $\begin{array}{l}\text { Kyriakopoulos, } \\
2016\end{array}$ & $\begin{array}{l}\text { Large-scale storage requires electrochemical storage applications, thermal energy storage is } \\
\text { in line with systematic approach system. } \\
\text { hydrogen-based energy storage is promising since it can link the main sectors of an energy } \\
\text { system, such as transportation and electricity, could be apply to a renewable power plant } \\
\text { and rely on hydrogen and fuel cell technologies. } \\
\text { The document evaluates the different factors of selection and use of energy storage } \\
\text { technologies, reviews advantages and disadvantages of each of them. }\end{array}$ \\
\hline [7] & Bengani, 2018 & $\begin{array}{l}\text { The expansion of network infrastructure has posed several challenges for companies, where } \\
\text { the traditional approach is to increase capacity to meet maximum demand and the authors } \\
\text { seek to incorporate energy storage systems (ESS), with the purpose of postponing } \\
\text { investments in infrastructure and strengthening by meeting maximum demand in the system; } \\
\text { giving reliability and stability, maximizing the benefits. } \\
\text { The method is based on optimizing the location of the device to observe contingencies and } \\
\text { the corresponding results of the nodal analysis. }\end{array}$ \\
\hline
\end{tabular}




\begin{tabular}{|c|c|c|}
\hline [8] & Reihani, 2016 & $\begin{array}{l}\text { The article proposes a algorithm for charging/discharging batteries, this with the aim of } \\
\text { smoothing the power charge curve and regulating the voltage of a distribution transformer. } \\
\text { These devices are bi-directional and help to supply power during peak usage periods and to } \\
\text { manage the network during low demand periods. } \\
\text { Control scenarios: in the first scenario you want to reduce the maximum peak where a fairly } \\
\text { precise performance is observed, its disadvantage is vulnerability to growth and in the } \\
\text { second case based on the first, a power smoothing algorithm is incorporated. This shows } \\
\text { that the BESS capacity is effective and helps to decrease spikes and increase power. }\end{array}$ \\
\hline [9] & Emmanuel, 2017 & $\begin{array}{l}\text { The photovoltaic (PV) system is an emerging paradigm of power generation, this is due to } \\
\text { the limitations and mismatches between its output power and load, which imply losses and } \\
\text { higher power. The article presents various scenarios for the implementation of photovoltaic } \\
\text { units and their scope in the smart grid. } \\
\text { The solution is analyzed with a Static Synchronous Compensator (STATCOM-BESS), } \\
\text { which is presented as a fast response and capacity, smoothing the photovoltaic support } \\
\text { avoiding critical contingencies. }\end{array}$ \\
\hline$[10]$ & Wu, 2019 & $\begin{array}{l}\text { This work analyzes the viability of frequency support in batteries, in the first section the } \\
\text { concept of frequency support BESS is defined, in section two the design, characteristics and } \\
\text { some types of batteries for frequency support are compared and finally in section Three, a } \\
\text { cost analysis is carried out and the international experiences that have been obtained in the } \\
\text { market are presented. }\end{array}$ \\
\hline [11] & Tang, 2009 & $\begin{array}{l}\text { This document analyzes the feasibility of using BESS to help the stability in steady state of } \\
\text { the electrical system, which is studied in three aspects: transfer capacity, small signal } \\
\text { stability and limit of stability in steady state; resulting in more active and reactive power } \\
\text { control and better damping in the system with BESS rather than with STATCOM. }\end{array}$ \\
\hline$[12]$ & Singh, 2010 & $\begin{array}{l}\text { In this document, a comparison is made between STATCOM, (BESS) and FACTS, which } \\
\text { seeks to show the effectiveness of the BESS controller. } \\
\text { In this document, the combination of STATCOM and BESS is analyzed and simulated, } \\
\text { showing the damping efficiency of the oscillation and the dynamic performance obtained. } \\
\text { The control by BESS is also demonstrated, which is more significant than STATCOM and } \\
\text { its incorporation helps system performance. of energy. }\end{array}$ \\
\hline$[13]$ & Kawakami, 2012 & $\begin{array}{l}\text { The Japanese network has renewable energy generation in its systems, which makes it find } \\
\text { many fluctuations in its system and therefore instability. This document presents the BESS } \\
\text { projects that have been built in Japan as a solution to the stability problems inherent in the } \\
\text { generation of renewable energy. }\end{array}$ \\
\hline [14] & Oka, 2013 & $\begin{array}{l}\text { The BESS are considered to have a high initial cost, so that in most photovoltaic generation } \\
\text { projects they are not considered, however, in this document the authors emphasize the long- } \\
\text { term economic study by proposing a BESS schedule of operations. optimal daily, } \\
\text { considering the use of the TABU algorithm and the net present value method. }\end{array}$ \\
\hline$[15]$ & Takeda, 2014 & $\begin{array}{l}\text { This document presents hybrid energy storage systems with batteries, in order to reduce } \\
\text { costs and size, using energy management algorithms through charge and discharge } \\
\text { simulations, thus achieving a } 36 \% \text { reduction in the cost of batteries compared to the typical } \\
\text { ones. BESS. Battery modules are also identified in two categories (high power, high energy) } \\
\text { that are tailored to the customer's needs. }\end{array}$ \\
\hline [16] & $\begin{array}{l}\text { Anvari- } \\
\text { Moghaddam, } \\
2015\end{array}$ & $\begin{array}{l}\text { Due to the use of renewable energy sources, microgrids appear, which can behave as an } \\
\text { energy center that adds units and can operate autonomously or connected to the network. In } \\
\text { this document, the authors propose a control scheme that helps reduce the short-term } \\
\text { operating cost of a microgrid connected to a residential network, taking into account the } \\
\text { costs of energy exchange and the cost of battery life per cycle. loading / unloading. }\end{array}$ \\
\hline [17] & Kim, 2016 & $\begin{array}{l}\text { In this document, the authors present a laboratory scale microgrid, using real batteries and } \\
\text { propose a real-time scheme (GFR) that provides an auxiliary service for rapid regulation in } \\
\text { the microgrid, enabling direct load control (DLC) to compensate the high frequency } \\
\text { components and thus improving the stability of the system. }\end{array}$ \\
\hline [18] & Xia, 2015 & $\begin{array}{l}\text { In most of the studies and simulations carried out with the BESS, the charge and discharge } \\
\text { characteristics of the batteries are taken into account, which can be simulated with great } \\
\text { precision compared to reality, but the same does not happen with control simulations with } \\
\text { the system connected to the network. In this document, the authors make a model for long- } \\
\text { term transient and electromechanical dynamic simulation of BESS connected to the network } \\
\text { using the PSASP software. }\end{array}$ \\
\hline
\end{tabular}




\begin{tabular}{|c|c|c|}
\hline [19] & Wang, 2017 & $\begin{array}{l}\text { To achieve effective use in voltage regulation with BESS, in this article, the authors propose } \\
\text { a method of managing powers to reduce power loss and minimize the impact of voltage } \\
\text { fluctuations from nearby nodes. to the BESS. }\end{array}$ \\
\hline [20] & Arif, 2017 & $\begin{array}{l}\text { The main disadvantage in using renewable energy is the unpredictable and fluctuating } \\
\text { production causing stability problems in the network, at this point the use of BESS becomes } \\
\text { important as a support for frequency control and voltage support. In this document the } \\
\text { authors present the simulation in DigSILENT for the case study to find the appropriate } \\
\text { location for the BESS in the system to dampen frequency fluctuations in case of failure. }\end{array}$ \\
\hline [21] & Sasmal, 2017 & $\begin{array}{l}\text { In this paper, the authors present a comparative analysis of energy compensation-based } \\
\text { smoothing techniques for photovoltaic systems with BESS using a simple moving window } \\
\text { algorithm. They also suggest using a hybrid energy system. } \\
\text { The system is confirmed by a bank of supercapacitors and vanadium dioxide batteries, in } \\
\text { order to mitigate the power fluctuation due to the penetration of photovoltaic generation. }\end{array}$ \\
\hline [22] & Barchi, 2018 & $\begin{array}{l}\text { In this document, the authors show a prototype photovoltaic generator (PV) and a BESS in a } \\
\text { shopping center in Italy, implementing a smart control strategy, in order to promote } \\
\text { efficiency, sustainability and contribute to the reduction of emissions. of CO, imposed by } \\
\text { the national government based on renewable energies. }\end{array}$ \\
\hline [23] & Sanduleac, 2018 & $\begin{array}{l}\text { In this document, the authors show the feasibility of using the BESS as the primary } \\
\text { frequency control in the electrical network, by simulating and using real measurements, } \\
\text { based on the charge / discharge algorithm to find limits on the daily cycles of the batteries, } \\
\text { finding its most efficient use and avoiding over wear }\end{array}$ \\
\hline [24] & Datta, 2018 & $\begin{array}{l}\text { In this document, the authors implement a simulation in Simulink / Matlab to analyze faults, } \\
\text { which has not been studied much previously, as a result they obtained that to minimize the } \\
\text { impact of DC faults in the AC Grid, optimized techniques should be studied as well to select } \\
\text { the size of the batteries and to improve safety in case of failures use a control algorithm. }\end{array}$ \\
\hline [25] & Jena, 2018 & $\begin{array}{l}\text { In this paper, is analyze the behavior and performance of a photovoltaic in a line-to-ground } \\
\text { fault microgrid with and without BESS using simulation methods in Simulink / Matlab, and } \\
\text { discover that the system better overlaps the fault with the inclusion of BESS and an estimate } \\
\text { of the battery life is calculated using a probabilistic approximation. }\end{array}$ \\
\hline [26] & Rathod, 2018 & $\begin{array}{l}\text { This document assesses the capacity of the BESS to support } \\
\text { have a balance among demand and supply of energy obtained by a wind farm, this is } \\
\text { analyzed through simulations in Simulink / Matlab using the energy buffering method and } \\
\text { achieving the maximum economic benefit with the maximum extraction of wind energy. . }\end{array}$ \\
\hline [27] & Li, 2019 & $\begin{array}{l}\text { Currently the most developed technologies for electrochemical batteries are lead acid and } \\
\text { lithium ion, in this document the lead-carbon battery is presented as the best option for } \\
\text { BESS, due to its adaptability to work at high temperatures and the capacity recovery in } \\
\text { charge-discharge cycles, improving the useful life for this system. }\end{array}$ \\
\hline [28] & Dubarry, 2017 & $\begin{array}{l}\text { The BESS in recent years have taken a fundamental role in renewable energy. In this } \\
\text { document, the authors present the efficiency of a real BESS located in Hawaii and its state } \\
\text { of degradation by daily use during } 3 \text { years, the laboratory tests estimate its remaining useful } \\
\text { life considering the effects of charge / discharge. }\end{array}$ \\
\hline [29] & Branco, 2018 & $\begin{array}{l}\text { The problem of microgrids in isolated places that have renewable energy generation is the } \\
\text { intermittent nature of the generation and that makes regulation difficult when there is excess } \\
\text { or deficit of supply, in many cases this is compensated by small thermal generators that } \\
\text { work with Diesel, which is a costly solution and also harmful to the environment, this makes } \\
\text { system operators rethink the use of RESS. In this document, the authors propose a } \\
\text { methodology to optimally size a BESS to solve the above problems, achieving a balance } \\
\text { between the integration of RES and the VPN in the system. }\end{array}$ \\
\hline [30] & $\begin{array}{l}\text { Noyanbayev, } \\
2018\end{array}$ & $\begin{array}{l}\text { The efficiency of a battery is studied in this document as the ratio of energy withdrawn and } \\
\text { returned to the grid in a charge cycle and that ratio in a range of operating points allows the } \\
\text { construction of efficiency maps, which are used to optimize the operation. } \\
\text { The authors perform simulations for BESS with a capacity of } 240 \mathrm{~kW} \text { and } 180 \mathrm{KW} \text {, finding } \\
\text { that most of the energy losses occur in the transformer and the inverter. }\end{array}$ \\
\hline
\end{tabular}




\begin{tabular}{|c|c|c|}
\hline [31] & $\begin{array}{l}\text { Crosa di } \\
\text { Vergagni, } 2020\end{array}$ & $\begin{array}{l}\text { The document proposes a control algorithm, with the aim of managing and controlling DER, } \\
\text { which is implemented in an energy resource management (ERM), seeking as objectives to } \\
\text { meet: (1) Control the energy consumption of the microgrid, before and after connection in } \\
\text { island mode (2) Maintain frequency. } \\
\text { The techniques (ERM) are developed in the Matlab environment, seek to operate in } \\
\text { microgrid scenarios and have the following objectives: reduce consumption peaks, control } \\
\text { energy consumption and participate in activities (ADR). }\end{array}$ \\
\hline [32] & Ahmadi, 2020 & $\begin{array}{l}\text { This document presents an energy management system (EMS) for a micro-grid network } \\
\text { (NMG), a two-level EMS is presented for an isolated structure, information is exchanged } \\
\text { externally and the internal EMS complies with the programming of energy to each } \\
\text { microgrid in case of failure in case of separation from the others. Using a Graduated } \\
\text { Demand Program (DRP), we seek to propose a tiered DRP and evaluate a comprehensive } \\
\text { NMG model. }\end{array}$ \\
\hline [33] & Liao, 2018 & $\begin{array}{l}\text { This document proposes a BESS sizing and scheduling optimization method.Using a } \\
\text { stochastic search optimization algorithm called e-DA (Electron Drift Algorithm) which } \\
\text { determines the best combination of batteries and smart inverters that maximize the total } \\
\text { revenue of photovoltaic systems. }\end{array}$ \\
\hline [34] & Grande, 2018 & $\begin{array}{l}\text { This document studies different benefits of using PV-BESS off-grid to charge electric } \\
\text { vehicles, using climate data from the city of Madrid. Consequently, the author's goal is to } \\
\text { design a system that requires a low investment, while providing an offline PV-BESS } \\
\text { system. }\end{array}$ \\
\hline [35] & Jannati, 2020 & $\begin{array}{l}\text { This document seeks to reduce energy changes using renewable energies controlled by the } \\
\text { charge / discharge cycles of BESS batteries. } \\
\text { The study is carried out in three stages, in stage one an algorithm is used that is responsible } \\
\text { for efficient energy monitoring. In the second stage, the energy from the wind farm is } \\
\text { injected into the grid and in the third stage an algorithm is proposed to load / unload the } \\
\text { BESS units. } \\
\text { The discussed method seeks to reduce BESS units, ensure utilities, and improve battery life }\end{array}$ \\
\hline [36] & Bai, 2019 & $\begin{array}{l}\text { This article conducts a comprehensive economic evaluation of the benefits of using reused } \\
\text { electric vehicle batteries in provincially distributed photovoltaic energy storage systems in } \\
\text { China. } \\
\text { The results show that, at present, the economic performance is more efficient observing it } \\
\text { from each state / municipality, in addition an economic viability is realized. }\end{array}$ \\
\hline [37] & Datta, 2020 & $\begin{array}{l}\text { This study uses a method to control an electric vehicle charging station which has a PV- } \\
\text { BESS implemented, this is done in order to reduce the demand for charging that may occur } \\
\text { at any time. The design seeks to reduce the demand for grid load during overload } \\
\text { conditions, providing smoothing to photovoltaic services. The research is analyzed from the } \\
\text { technical perspective and concludes that a reduction of almost } 138 \% \text { in transformer } \\
\text { overload can be achieved, which can regulate its output power to reduce transformer } \\
\text { overload. }\end{array}$ \\
\hline$[38]$ & Howlader, 2016 & $\begin{array}{l}\text { By implementing Distributed Renewable Generators (GRD) in the system, its penetration } \\
\text { increases causing there is no balance between supply and demand. The article proposes a } \\
\text { smart grid model in which it is desired to integrate (GRD) and energy storage systems on } \\
\text { the supply side and smart homes on the demand side. It is analyzed from different climatic } \\
\text { conditions and different demand response rates, concluding that the benefits of using the } \\
\text { smart grid model increase significantly when the demand response is considered. }\end{array}$ \\
\hline [39] & Jo, 2019 & $\begin{array}{l}\text { The document proposes an equivalent power system circuit modeling (EPSC) method which } \\
\text { simulates an energy system using constant modification method, analyzed the frequency } \\
\text { changes in the system before and after integrating BESS to regulate the frequency, giving In } \\
\text { conclusion, BESS improves the response to extreme demand }\end{array}$ \\
\hline [40] & Rallabandi, 2019 & $\begin{array}{l}\text { The article analyzes the configuration, design and operation of the photovoltaic (PV) } \\
\text { systems connected to the } 10 \mathrm{MW} \text { grid, simulating the different scenarios such as periods of } \\
\text { low irradiation, constant power and superior irradiation using the PSCAD software. The } \\
\text { simulations of a 14-node IEEE bus connected to an independent inverter are performed and } \\
\text { the advantages and disadvantages that occur when doing it are observed. One of them is to } \\
\text { control the smoothing of energy output to the photovoltaic system. }\end{array}$ \\
\hline
\end{tabular}

\section{CLASSIFICATION TABLE}


A classification is made where it is possible to identify at what level of adoption of the distributed energy resources it is and what is the approach given according to its element of transformation, as can be seen in figure 1.

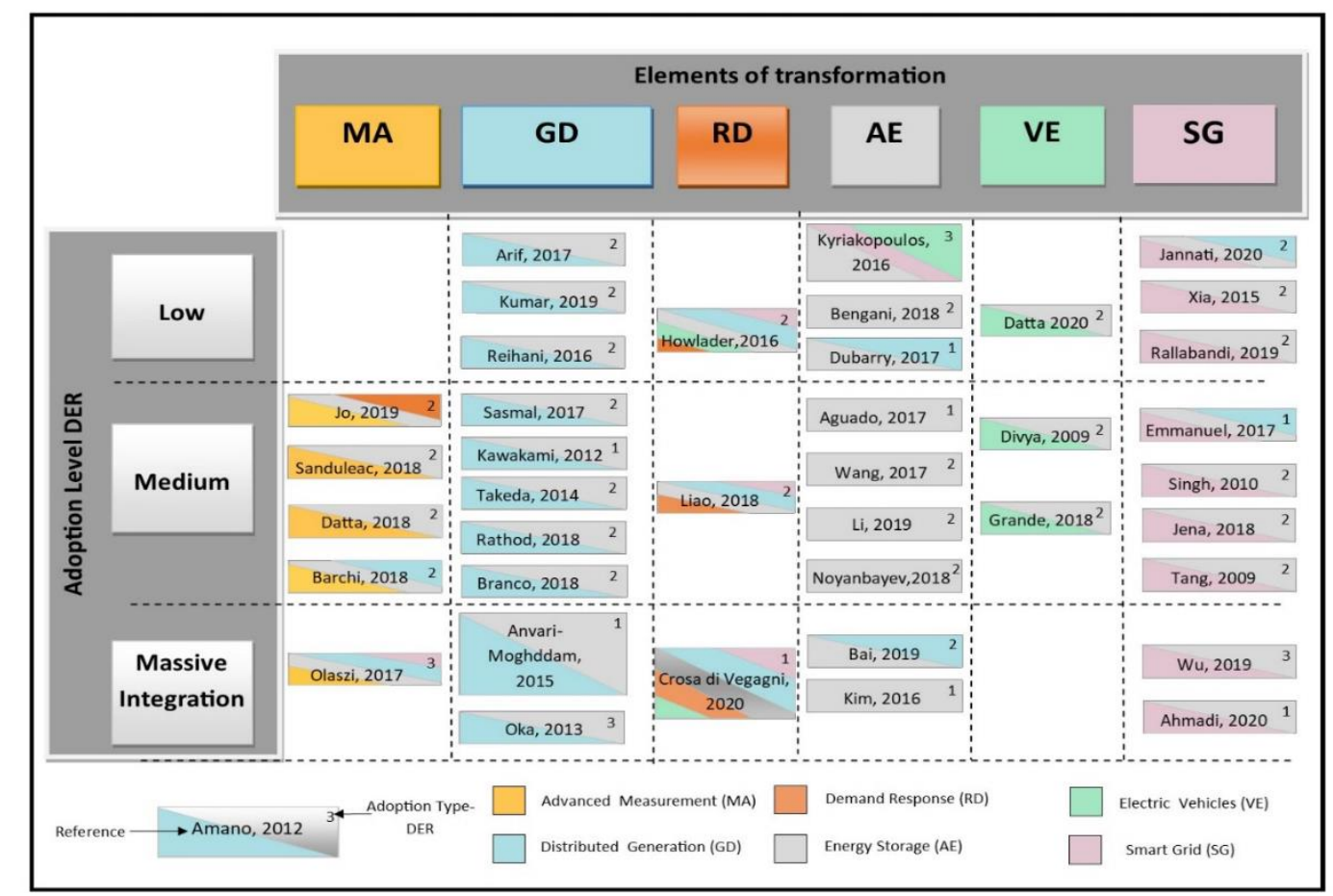

Figure 1: Classification of the Articles of the Adoption Level and its Transformation Element.

It will be observed in the upper right part the type of DER adoption where the articles are most focused according to the following levels:

\section{Massive Integration}

- $\quad$ sustainable microgrids (embedded / hard-to-reach areas)

- New business models

- Operation and distributed markets

\section{Medium}

- implementation of microgrids

- DER resource optimization

\section{Low}

- $\quad$ Research in smart grids

- Analysis of DER resource scenarios

- standardization and regulation

\section{CONCLUSIONS}

The most relevant information in which the adoption levels were covered and the elements of transformation of distributed 
energy resources (DER) were recognized and recorded in such a way that a classification is analyzed in which it is observed that the topics most treated in The literature is energy storage, distributed generation and Smart Grids, and where the least information is found is in response to demand, advanced metering and electric vehicles. This is done so that other authors have a more general vision of what topics to focus on to investigate.

\section{REFERENCES}

1. Colombia inteligente, (2020). “Recursos energéticos distribuidos: acciones para su integración,"

2. Aguado, J. A., de la Torre, S., \& Triviño, A. (2017). Battery energy storage systems in transmission network expansion planning. Electric Power Systems Research, 145, 63-72. https://doi.org/10.1016/j.epsr.2016.11.012

3. Ahmadi, S. E., \& Rezaei, N. (2020). A new isolated renewable based multi microgrid optimal energy management system considering uncertainty and demand response. International Journal of Electrical Power and Energy Systems, 118(December 2019). https://doi.org/10.1016/j.ijepes.2019.105760

4. Anvari-Moghaddam, A., Dragicevic, T., Vasquez, J. C., \& Guerrero, J. M. (2015). Optimal utilization of microgrids supplemented with battery energy storage systems in grid support applications. 2015 IEEE 1st International Conference on Direct Current Microgrids, ICDCM 2015, 57-61. https://doi.org/10.1109/ICDCM.2015.7152010

5. Arif, S., \& Aziz, T. (2017). Impact of battery energy storage system on post-fault frequency fluctuation in renewable integrated microgrid. ECCE 2017 - International Conference on Electrical, Computer and Communication Engineering, (September 2014), 594-598. https://doi.org/10.1109/ECACE.2017.7912974

6. Bai, B., Xiong, S., Song, B., \& Xiaoming, M. (2019). Economic analysis of distributed solar photovoltaics with reused electric vehicle batteries as energy storage systems in China. Renewable and Sustainable Energy Reviews, 109(August 2018), 213-229. https://doi.org/10.1016/j.rser.2019.03.048

7. Barchi, G., Miori, G., Moser, D., \& Papantoniou, S. (2018). A Small-Scale Prototype for the Optimization of PV Generation and Battery Storage through the Use of a Building Energy Management System. Proceedings - 2018 IEEE International Conference on Environment and Electrical Engineering and 2018 IEEE Industrial and Commercial Power Systems Europe, EEEIC/I and CPS Europe 2018, 1-5. https://doi.org/10.1109/EEEIC.2018.8494012

8. Bengani, T. M., \& Kombe, J. A. (2018). Using energy storage to defer infrastructure investment, (September).

9. Branco, H., Castro, R., \& Setas Lopes, A. (2018). Battery energy storage systems as a way to integrate renewable energy in small isolated power systems. Energy for Sustainable Development, 43, 90-99. https://doi.org/10.1016/j.esd.2018.01.003

10. Crosa di Vergagni, M., Massucco, S., Saviozzi, M., Silvestro, F., Monachesi, F., \& Ragaini, E. (2020). A quasi-optimal energy resources management technique for low voltage microgrids. International Journal of Electrical Power and Energy Systems, 121(October 2019). https://doi.org/10.1016/j.ijepes.2020.106080

11. Datta, U., Kalam, A., \& Shi, J. (2018). Battery energy storage system for transient frequency stability enhancement of a largescale power system. 2017 Australasian Universities Power Engineering Conference, AUPEC 2017, 2017-Novem, 1-5. https://doi.org/10.1109/AUPEC.2017.8282465

12. Datta, U., Kalam, A., \& Shi, J. (2020). Smart control of BESS in PV integrated EV charging station for reducing transformer overloading and providing battery-to-grid service. Journal of Energy Storage, 28(February), 101224. https://doi.org/10.1016/j.est.2020.101224

13. Divya, K. C., \& Østergaard, J. (2009). Battery energy storage technology for power systems-An overview. Electric Power Systems Research, 79(4), 511-520. https://doi.org/10.1016/j.epsr.2008.09.017 
14. Dubarry, M., Devie, A., Stein, K., Tun, M., Matsuura, M., \& Rocheleau, R. (2017). Battery Energy Storage System battery durability and reliability under electric utility grid operations: Analysis of 3 years of real usage. Journal of Power Sources, 338(March 2016), 65-73. https://doi.org/10.1016/j.jpowsour.2016.11.034

15. Emmanuel, M., \& Rayudu, R. (2017). Evolution of dispatchable photovoltaic system integration with the electric power network for smart grid applications: A review. Renewable and Sustainable Energy Reviews, 67, $207-224$. https://doi.org/10.1016/j.rser.2016.09.010

16. Grande, L. S. A., Yahyaoui, I., \& Gómez, S. A. (2018). Energetic, economic and environmental viability of off-grid PV-BESS for charging electric vehicles: Case study of Spain. Sustainable Cities and Society, 37(December 2017), 519-529. https://doi.org/10.1016/j.scs.2017.12.009

17. Howlader, H. O. R., Matayoshi, H., \& Senjyu, T. (2016). Distributed generation integrated with thermal unit commitment considering demand response for energy storage optimization of smart grid. Renewable Energy, 99, $107-117$. https://doi.org/10.1016/j.renene.2016.06.050

18. Jannati, M., \& Foroutan, E. (2020). Analysis of power allocation strategies in the smoothing of wind farm power fluctuations considering lifetime extension of BESS units. Journal of Cleaner Production, 266. https://doi.org/10.1016/j.jclepro.2020.122045

19. Jena, S., Sinha, P., Satpathy, P. R., Khatua, S., Sharma, R., \& Kar, S. K. (2018). Performance analysis of solar PV based microgrid with and without BESS estimating the expected battery life. International Conference on Technologies for Smart City Energy Security and Power: Smart Solutions for Smart Cities, ICSESP 2018 - Proceedings, 2018-Janua, 1-6. https://doi.org/10.1109/ICSESP.2018.8376722

20. Jo, H., Kim, C., \& Han, S. (2019). Performance Evaluation of BESS for Korean Power System Using Equivalent Power System Circuit Model. IFAC-PapersOnLine, 52(4), 246-251. https://doi.org/10.1016/j.ifacol.2019.08.200

21. Kawakami, N., \& Iijima, Y. (2012). Overview of battery energy storage systems for stabilization of renewable energy in Japan. 2012 International Conference on Renewable Energy Research and Applications, ICRERA 2012, 1-5. https://doi.org/10.1109/ICRERA.2012.6477391

22. Kim, Y. J. (2016). Experimental study of battery energy storage systems participating in grid frequency regulation. Proceedings of the IEEE Power Engineering Society Transmission and Distribution Conference, 2016-July, 1-5. https://doi.org/10.1109/TDC.2016.7520058

23. Kumar, A., Meena, N. K., Singh, A. R., Deng, Y., He, X., Bansal, R. C., \& Kumar, P. (2019). Strategic integration of battery energy storage systems with the provision of distributed ancillary services in active distribution systems. Applied Energy, 253(May), 113503. https://doi.org/10.1016/j.apenergy.2019.113503

24. Kyriakopoulos, G. L., \& Arabatzis, G. (2016). Electrical energy storage systems in electricity generation: Energy policies, innovative technologies, and regulatory regimes. Renewable and Sustainable Energy Reviews, 56, 1044-1067. https://doi.org/10.1016/j.rser.2015.12.046

25. Li, J., Zhang, T., Duan, S., \& Li, H. (2019). Design and implementation of lead-carbon battery storage system. IEEE Access, 7 , 32989-33000. https://doi.org/10.1109/ACCESS.2019.2904067

26. Liao, J. T., Chuang, Y. S., Yang, H. T., \& Tsai, M. S. (2018). BESS-Sizing Optimization for Solar PV System Integration in Distribution Grid. IFAC-PapersOnLine, 51(28), 85-90. https://doi.org/10.1016/j.ifacol.2018.11.682

27. Noyanbayev, N. K., Forsyth, A. J., \& Feehally, T. (2018). Efficiency analysis for a grid-connected battery energy storage system. 
Materials Today: Proceedings, 5(11), 22811-22818. https://doi.org/10.1016/j.matpr.2018.07.095

28. Oka, Y., \& Yokoyama, A. (2013). Optimal operation scheduling and economical evaluation method of battery energy storage system in power system with a large penetration of photovoltaic generation. 2013 IEEE Grenoble Conference PowerTech, POWERTECH 2013, 1-6. https://doi.org/10.1109/PTC.2013.6652320

29. Olaszi, B. D., \& Ladanyi, J. (2017). Comparison of different discharge strategies of grid-connected residential PV systems with energy storage in perspective of optimal battery energy storage system sizing. Renewable and Sustainable Energy Reviews, 75(November 2016), 710-718. https://doi.org/10.1016/j.rser.2016.11.046

30. Rallabandi, V., Akeyo, O. M., Member, S., Jewell, N., Member, S., \& Ionel, D. M. (2019). Multi-MW Grid Connected PV Systems. IEEE Transactions on Industry Applications, 55(1), 638-647. https://doi.org/10.1109/TIA.2018.2864696

31. Rathod, D. N., \& Thakare, A. P. (2018). Simulation for the most favorable competence of the BESS for the wind mills. 2017 International Conference on Computing, Communication, Control and Automation, ICCUBEA 2017, 1-5. https://doi.org/10.1109/ICCUBEA.2017.8463803

32. Reihani, E., Sepasi, S., Roose, L. R., \& Matsuura, M. (2016). Energy management at the distribution grid using a Battery Energy Storage System (BESS). International Journal of Electrical Power and Energy Systems, 77, 337-344. https://doi.org/10.1016/j.ijepes.2015.11.035

33. Sanduleac, M., Toma, L., Eremia, M., Boicea, V. A., Sidea, D., \& Mandis, A. (2018). Primary Frequency Control in a Power System with Battery Energy Storage Systems. Proceedings - 2018 IEEE International Conference on Environment and Electrical Engineering and 2018 IEEE Industrial and Commercial Power Systems Europe, EEEIC/I and CPS Europe 2018, (727481), 15. https://doi.org/10.1109/EEEIC.2018.8494490

34. Sasmal, R. P., Sen, S., \& Chakraborty, A. (2017). Solar photovoltaic output smoothing: Using battery energy storage system. 2016 National Power Systems Conference, NPSC 2016, 1-5. https://doi.org/10.1109/NPSC.2016.7858894

35. Singh, B., \& Hussain, Z. (2010). Application of Battery Energy Storage System (BESS) in voltage control and damping of power oscillations. 2010 5th International Conference on Industrial and Information Systems, ICIIS 2010, 514-519. https://doi.org/10.1109/ICIINFS.2010.5578649

36. Takeda, K., Takahashi, C., Arita, H., Kusumi, N., Amano, M., \& Emori, A. (2014). Design of hybrid energy storage system using dual batteries for renewable applications. IEEE Power and Energy Society General Meeting, 2014-Octob(October), 1-5. https://doi.org/10.1109/PESGM.2014.6938860

37. Tang, S., Yang, H., Zhao, R., \& Geng, X. (2009). Influence of battery energy storage system on steady state stability of power system. Proceedings - The 12th International Conference on Electrical Machines and Systems, ICEMS $2009,1-4$. https://doi.org/10.1109/ICEMS.2009.5382739

38. Wang, W., He, W., Cheng, J., Huang, X., \& Liu, H. (2017). Active and reactive power coordinated control strategy of battery energy storage system in active distribution network. Proceedings - 2017 32nd Youth Academic Annual Conference of Chinese Association of Automation, YAC 2017, 462-465. https://doi.org/10.1109/YAC.2017.7967453

39. Wu, Y. K., \& Tang, K. T. (2019). Frequency support by BESS - Review and analysis. Energy Procedia, 156(September 2018), 187-198. https://doi.org/10.1016/j.egypro.2018.11.126

40. Xia, T., Li, M., Zi, P., Tian, L., Qin, X., \& An, N. (2016). Modeling and simulation of Battery Energy Storage System (BESS) used in power system. Proceedings of the 5th IEEE International Conference on Electric Utility Deregulation, Restructuring and Power Technologies, DRPT 2015, 2120-2125. https://doi.org/10.1109/DRPT.2015.7432597 
